\title{
The Devil is in the (Bio)diversity: Private Sector "Engagement" and the Restructuring of Biodiversity Conservation
}

\author{
Kenneth Iain MacDonald \\ Department of Geography and Program in Planning, University of Toronto, \\ Canada; \\ kmacd@utsc.utoronto.ca
}

\begin{abstract}
Intensified relations between biodiversity conservation organizations and privatesector actors are analyzed through a historical perspective that positions biodiversity conservation as an organized political project. Within this view the organizational dimensions of conservation exist as coordinated agreement and action among a variety of actors that take shape within radically asymmetrical power relations. This paper traces the privileged position of "business" in aligning concepts of sustainable development and ecological modernization within the emerging institutional context of the Convention on Biological Diversity and the Global Environment Facility in ways that help to secure continued access to "nature as capital", and create the institutional conditions to shape the work of conservation organizations. The contemporary emergence of business as a major actor in shaping contemporary biodiversity conservation is explained in part by the organizational characteristics of modernist conservation that subordinates it to larger societal and political projects such as neoliberal capitalism.
\end{abstract}

Keywords: biodiversity, conservation, organizations, private-sector engagement

In January 2009 Friends of the Earth International (FOEI), which bills itself as "the world's largest grassroots environmental network" withdrew their membership in the International Union for the Conservation of Nature (IUCN), an organization that is made up of a wide collection of non-governmental environmental organizations and governmental environmental agencies. ${ }^{1}$ In the letter of notification, which was addressed to the Director General of IUCN, the International Chair of FOEI clearly states that the main reason for the withdrawal was their "concern about the corporate partnership between Shell and the IUCN".2 More specifically, the letter cited two primary concerns with the partnership. First, while the partnership would not likely have any meaningful impact on Shell's activities it seemed to be silencing IUCN's willingness to critique the negative social and environmental consequences associated with Shell's practices and thereby compromising the ability of member organizations to work in effected communities. Second, and perhaps more importantly, attempts 
by the membership to terminate the relationship between IUCN and Shell had been stymied by the bicameral structure of IUCN, which divides the membership according to their status as governmental or non-governmental organizations (NGOs) and effectively establishes two "houses" of membership.

The second point refers to a drama of sorts that played out during the World Conservation Congress (WCC) held in Barcelona in October 2008. The WCC is a convention of the membership of IUCN held once every 4 years and is divided into a "Forum"-with paper sessions and workshops-and a "Members Assembly" during which the entire membership votes on motions put forward by small groups of members. Motions that pass both "houses" of the assembly become resolutions that are intended to guide the activities of the IUCN Secretariat for the next 4 years. During the Barcelona WCC a number of motions put forward by members indicated a growing tension over the engagement of the Secretariat with private sector actors, and the increasing re-orientation of the organization around practices informed by ideologies of ecological modernization. The most blunt of these was Motion 107 that called for the termination of the IUCN's "agreement" with Shell. As the BBC reported, "the vote, when it came, was the most eagerly anticipated of the congress". 3 When the dust of debate had settled, the motion was defeated. Despite the fact that the motion carried over $60 \%$ of the popular vote and that $70 \%$ of NGO members had voted in support, most government delegates voted against and blocked the motion. ${ }^{4}$ This blockage occurred because IUCN statutes mandate the calculation of votes within governmental and non-governmental "houses" and only allow a motion to pass if it secures an absolute majority in both "houses". The perception among many members was that the popular will of the membership had been blocked by an alliance between the Secretariat which, through a series of statements and other gestures, ${ }^{5}$ had actively opposed the motion to terminate the agreement, private sector actors and State members. ${ }^{6}$

The subsequent withdrawal of FOEI from IUCN is but one example of a growing ideological and material divide between large international conservation organizations and smaller groups that orient themselves around "the grassroots". While visible expressions of this divide are relatively recent, in this paper I make the case that the grounds for the shift in the ideological and practical orientation of large conservation organizations has been developing over the last two decades, and that this has happened through a structured process involving an ideological alignment of the emergent concepts of sustainable development and ecological modernization and the development of a new international institutional context for environmental governance that minimized the threat, to business, of regulatory control over access to natural capital. The first part of the paper outlines this process of ideological alignment 
and the way in which it shaped the emergence of a new international institutional context. The second part of the paper considers the implications of this shift, specifically how this new institutional context brought into being new grounds for organizational legitimacy and new sources of funding that encouraged the development of entrepreneurial practices within large conservation organizations and directed them toward intensified engagement with private sector actors. ${ }^{7}$ In the course of making this case, I also demonstrate the importance of interpreting these actions through the lens of organizational theory and make the case that the contemporary emergence of business as a major actor in shaping contemporary biodiversity conservation is explained in part by the organizational characteristics of modernist conservation that subordinates it to larger societal and political projects such as neoliberal capitalism.

Given the significant global reach of non-governmental conservation organizations (NGCOs) and their influence in national and global environmental governance, there is a need to understand what mobilizes fundamental ideological and organizational shifts within these organizations; the processes through which such shifts in focus spread; the effect of these shifts on processes of knowledge production, policy development, and conservation programming and implementation; and how they contribute to a reorientation of biodiversity conservation targets, and outcomes, thereby creating new ecological realities through reformulated practices of biodiversity conservation. This paper seeks to fill this gap in knowledge by exploring the conditions that have led to the restructuring of biological diversity conservation.

\section{The Organization of Biodiversity Conservation}

Since the rise of organizational environmentalism in the 1960s, business and biodiversity conservation organizations have lived in two distinct and heavily bounded worlds. The dominant view was that they embraced values, approaches and missions that were deeply incompatible. Over the past decade, however, a significant shift has occurred that has seen an increase in the forms of interaction between these two sets of actors (Secretariat of the Convention on Biological Diversity-CBD Secretariat 2004). Evidence of this is found in the restructuring of international NGCOs to accommodate various forms of relationships with private sector actors. This is revealed in programmatic initiatives that have assumed the common moniker of "Business and Biodiversity" initiatives. While the historical track of this restructuring is not well studied, such initiatives include:

1 The establishment of organizational units inside NGCOs dedicated to establishing, fostering and managing collaborative relationships between NGCOs and private sector interests; 
2 Incentive programs developed at state and supra-state levels to promote the establishment of such relationships through subsidies;

3 Increase in conservation programming focused on market-based conservation incentives and grounded in a dubious equations between ecological modernization and sustainable development;

4 The establishment of NGCO/private sector networks connected through interaction among a set of common individuals.

To understand the rise in the association between private sector actors and biodiversity, it is necessary to view modernist biodiversity conservation as an organized political project. ${ }^{8}$ There are two important dimensions to this claim. First is the recognition that the organizational dimensions of conservation exist as coordinated agreement and action among a variety of actors that take shape within radically asymmetrical power relations of ideology and practice, both of which reciprocally relate to objectives set by organizational actors. Second, the practical expression of that coordination exists as organized social groupsconservation organizations - that have emerged out of specific historical contexts. Both aspects of "organization" in this context imply the promotion of certain ideological perspectives that are worked out through processes of coordinated agreement, and implemented through the actions of conservation organizations. These are by no means exclusive processes. Indeed the actions of conservation organizations are directed through the ideological configurations brought to bear upon them by the coordinated agreement of relevant actors or what have come to be known as "stakeholders". Understanding the contemporary emergence of business as a major actor in shaping contemporary biodiversity conservation requires understanding the emergence of conservation organizations in relation to the coordinating action of the dominant ideological interests that underlie these broader political projects. Biodiversity conservation has never really driven environmental agendas. Rather, it has been an instrument in much larger political projects such as nationalism, colonialism and capitalism. This means that conservation policy and practice, whether developed within governmental or NGOs, is structured in relation to broader and longer term political goals. ${ }^{9}$ This point is important in understanding the entrance of a seemingly new actor into the organization of biodiversity conservation - what is loosely labeled as "business" 10 in the standard international relations literature-because it signals a number of important developments: a shift in the larger political projects that drive conservation; an alteration in the ideological configurations that constitute the social ground on which conservation can be practiced; and the development of an international institutional context for biodiversity conservation that reflected those changes. 


\section{The Emergence of Sustainability}

As with much of the environmental movement, biodiversity conservation underwent a significant change in the 1980s with the emergence of the concept of sustainability and, more importantly, its rapid incorporation into political rhetoric and an emerging institutional structure of global environmental governance. The concept gained credence among conservation practitioners with the emergence of the 1980s World Conservation Strategy (WCS) jointly published by the IUCN, United Nations Environment Programme (UNEP) and the World Wide Fund for Nature (WWF). The WCS had three specific goals: to maintain essential ecological processes and life support systems; to preserve genetic diversity; and to ensure the sustainable utilization of species and ecosystem, and it led conservation planners to focus on alignments between conservation, development and sustainability, most notably in the form of "sustainable use" and "incentive-based" conservation programming (Adams and Hutton 2007). The WCS, however, was more than simply a policy document. It was the initial step in an attempt to structure the establishment of coherent national conservation strategies around the world and became the basis for the rapid expansion of IUCN, WWF UNDP and, subsequently, other major conservation organizations into international project-based conservation programming. The articulation of sustainability, development and conservation expressed in the WCS and subsequent national conservation strategies successfully mobilized donor funds, most significantly from USAID and the Global Environment Facility (GEF), which drove the boom in integrated conservation and development projects and the focus on "communitybased natural resource management" that assumed dominance in international conservation organizations during the 1990s. ${ }^{11}$

It is not difficult to read the WCS, particularly its tentative alignment with the use of "market mechanisms" to achieve conservation goals, as a document that anticipates the shift from a decade of effective state environmental regulation to a period of government resistance to such regulation that emerged under the Thatcher administration in Britain in the late 1970s and was about to emerge in the USA-one that would explicitly equate "nature" and capital and consequently subject the protection of nature to market forces (Turner 1982). In essence, the rise of sustainability in the 1980s, can be understood as a function of its position as a compromise conceptual device meant to address the environmental crisis of consumption and the apparent contradiction of capitalism - the destruction of the physical environment upon which it depends for continued growth-without alienating the governmental bodies upon which conservation had come to depend. Despite its retrospective failings, the concept of sustainable development gained popularity quickly and, partially as a function of 
a seductive vagueness, incorporated what had been an oppositional environmental politics into a mainstream institutional context (Brand and Görg 2008; Geisinger 1999; Hildyard 1993; O'Connor 1994; Sneddon 2000; Worster 1993). To a large extent this was achieved through a language that sought to replace protest and conflict with consensus and consent by claiming that economic and environmental goals were compatible, a message that underpinned the popularity and quick, if superficial, embrace of Our Common Future (WCED 1987; cf Beder 2006; Tokes 2001). Conservation organizations and other actors in the broader environmental movement quickly adopted and popularized the concept, even as they were attempting to define it. But they were not alone in this. Other actors were engaged in what was in essence an ideological struggle to gain a dominant position in the attempt to define the terms under which sustainable development would become a legitimizing instrument.

\section{Positioning Sustainable Development as Ecological Modernization}

While the concept of sustainability was under production in the 1980s a parallel perspective, ecological modernization (EM), came into being as a challenge, more than a compromise, to the popular assertions that human societies needed to seriously grapple with selflimitation (see Moland Spaargaren 2000). This response is far less a coherent theory than a loosely interrelated collection of concepts and mechanisms developed in an attempt to produce a version of capitalism that can address its own contradictions while retaining control over the regulatory tendencies of governments that might threaten the capacity for private accumulation (Ashford 2002; Hajer 1995; Keil and Desfor 2003; Tokes 2001). While the concept of EM initially developed in Europe, it has been incorporated into the antiregulatory and antigovernment ideological revolution that accompanied the ascendance of many neoliberal administrations around the world. As a response to the regulatory approaches to environmental management that accompanied the rise of popular environmentalism during the late 1960s and 1970s, ecological modernization challenged the restrictions on access to environmental resources and the impingement on capital accumulation posed by regulation. As an alternative, it framed a technocentric and interventionist variant of environmentalism that highlights the application of science, market forces and managerial ingenuity through instruments such as tradable permit schemes and markets in what have come to be known as ecosystem servicesthe very term being a sign of the degree to which "nature" has become an element in capitalist processes of ideological domination. EM also seeks to promote flexibility and regulatory freedom to take 
advantage of industry's supposed potential to engage in technological innovation; encourages more voluntarism and stakeholder participation in governance; and "promotes demand-side policies focused on mobilizing 'green' consumer behavior" (Ashford 2002:1417). The primary assumption behind EM is that "sustainable futures can be attained under conditions of a continuously growing capitalist economy" and it is in this assumption that ecological modernization asserts its unanimity with sustainable development (Keil and Desfor 2003:30).

My point here is that ecological modernization is positioned as part of an overall strategy that defines sustainable development, and provides the intellectual leverage to challenge regulatory impulses whenever and wherever they appear (cf Bernstin 2001). Its primary claim is that the historical ecological contradictions of capitalism can be resolved through new strategies of accumulation and that these should rightly be the main mode of environmental protection for the planet (cf Ervine 2007). ${ }^{12}$ Within this frame, the survival of the natural world becomes a residual product of industrial and social processes as ecological modernization asserts the primacy of society over nature and "presupposes the hegemony of capitalist relations over other forms of social organization" (Keil and Desfor 2003:32). This is a particularly neoliberal view of the world; one that, even as it clouds the question of what kinds of nature are economically, socially and ecologically just (as opposed to efficient and marketable), speaks of win-win situations. It is also a view that has penetrated into international conservation organizations. In the words of a former IUCN employee discussing the origins of the Business and Biodiversity Unit:

So we set up this business unit, and the idea we had was, if we were going to say "Is biodiversity a business proposition? Can people make money by saving nature? And can we get nature saved by people making money?" ... can we expand the set of instruments out there that conserve nature by using capitalist tools? This was the whole thing. And my slogan for the program was "making capitalism work for conservation." That was the slogan of the business unit.

Despite criticisms of the ways in which ecological modernization in practice seemingly contradicts the goals of conservation organizations, it has become a key element in the discursive configuration of "solutions" to the problem of biodiversity loss. It has also secured a position at the core of project activities among leading conservation organizations in a way that involves a full accommodation of the existing capitalist order. Indeed, a survey of the websites of major conservation organizations indicates that they have become important locales for the articulation of ecological modernization projects ${ }^{13}$. Here then we find the first hints of a new political project structuring the activities of biodiversity conservation, and it reveals a sharp move away from a high modernist 
phase of conservation. It also suggests a move in which some of the more marginal voices that arose in the wake of high modernism are being marginalized once again as their demands for maintaining and improving the biological diversity that underpins conditions of ecological resilience have lost primacy to concerns for efficiency, competitiveness, marketability, flexibility and development.

To understand this shift and the speed with which EM as sustainable development has penetrated conservation organizations, it is necessary to situate it within the shifting institutional and organizational context of biodiversity conservation that developed through the 1980s and 1990s. This shift had three primary components, some of which were seen as "successes" of conservation: the expansion of project-based conservation that took advantage of the extension of neoliberal practices; the appearance of new conservation organizations, like Conservation International, grounded in entrepreneurial strategies; and the emergence of a new institutional network of environmental governance that actualized external control on conservation organizations.

These were not mutually exclusive developments and all were structured by the prevalence of neoliberal forms of governance that emerged during the 1980s. These new modes of governance, in many cases imposed by multilateral financial institutions and their associated structural adjustment programs, lead to reduced state investment in long-term biodiversity protection, especially in the fiscally constrained states of the "global south" (James, Green and Paine 1999; Lapham and Livermore 2003; Mansourian and Dudley 2008; Pearce and Palmer 2001; Redclift 1995; Reed 1992). This retrenchment, however, also created the political opportunity for large conservation organizations to assume heightened responsibility for environmental management in many of those locales. Through the 1980s and 1990s conservation organizations rapidly expanded in size, and budget, and engaged in "mission shift" moving from a focus on knowledge production, and policy consultation, to fund raising and project implementation. Much of this expansion was achieved haphazardly through the establishment of country offices or regional programs that were supported by the increasing linkage between biodiversity conservation and sustainable development that had been articulated in the World Conservation Strategy. As one former IUCN staff member put it:

The whole organization was Byzantine. Well, the organization is ... the business model of the organization is completely undeveloped. It makes no sense. But by this time in the 90 s they had these so-called Regional Country Programs, so-called programs, that had developed out of a conservation and development fund-raising drive ... in the 80s. They were projects and then they became so big that IUCN, which only had about 12 people in headquarters that would service the Commissions and service the meeting every few 
years... They brought it inside of the tent and it was bigger than headquarters, and you know it was all optics, there was something in Pakistan and there was something in Kenya and it just didn't ... there was no game plan, nothing (interview, May 2008).

Regardless of the chaotic mode of expansion, this increased global presence helped conservation organizations acquire legitimacy through their participation in the creation and implementation of international legal instruments (Flitner 1999; Jamison 1996; MacDonald 2005; Taylor and Buttel 1992). This led to the increasing use of NGCOs as vehicles to channel development funds (cf Maragia 2002), which subsequently spurred greater international growth (Reimann 2006). The combination of an international presence and institutional legitimacy reciprocally enhanced the capacity of transnational NGCOs to define global environmental problems and their solutions, and to influence national politics and decision-making. NGCOs, however, did not have the fiscal resources typical of states and needed to develop not only dependable sources of funding but also cross-sector legitimacy. Both of these needs came to be satisfied through a continued embrace of the commodification of nature under neoliberalism that had been established in the World Conservation Strategy. Organizations sought to develop modes through which biodiversity could pay for its own salvation by extending the mechanisms through which nature could be "conceived in the image of capital" into new spaces, and used this representation as the basis for the rational management of "nature as capital" (O'Conner 1994:131; Coronil 2000). Under the structuring influence of an "external" environment increasingly governed by the global institutionalization of neoliberalism, organizations that had sought to extend their spatial reach readily adjusted their operating practice and organizational structure to better align with this shifting institutional context. In need of the funds that were increasingly channeled through this institutional structure, conservation organizations not only pursued projects that readily sought to convert the use value of nature to exchange value in any number of small communities around the world, but they openly made conservation an instrument for the accumulation of capital and a vehicle through which capital interests could gain access to sites of "nature as capital". This typically occurred with the full support of relevant governments as they derived a share of revenue from what came to be known as "market-based" incentive projects. With GEF and UNDP support, these projects quickly gained ground in the 1990s as trophy hunting, bioprospecting, and ecotourism became the manifestation of a commoditized nature reoriented to serve elite and corporate interests but that would, under the rhetoric of "community-based conservation", also provide a "profit" for local communities (Hayden 2003; McAfee 1999; MacDonald 2004a, 2004b). ${ }^{14}$ 
Just as significant, this access to the potential for capital accumulation also produced a context in which "partnerships" become a vehicle through which NGCOs and private sector actors can pursue their diverse goals (Gulbrandsen and Holland 2001). With the retrenchment of state agencies, and the increasing gatekeeping role played by NGCOs, partnerships are increasingly viewed as the primary mechanism through which a negotiated form of biodiversity conservation (between various private and public actors) might be forged. Indeed, NGCOs are increasingly representing themselves as locales in which the historical opposites of private interest and environmental well-beingof profit incentive and environmental good-might be reconciled (eg Conservation International 2005; IUCN 2006). And it is this "reconciliation" that conservation organizations now represent as the "leading edge" of conservation practice. But these exaggerated claims to be on the leading edge mask the degree to which their practice is structured not only by the alignment of sustainable development and ecological modernization, but in the way this alignment was both born of and gave shape to a new institutional context of conservation in the late 1980s and through the 1990s.

\section{Negotiating the Access of Capital: the Development of a} "Global" Institutional Context for Biodiversity Conservation

A defining moment in the formalization of the new institutional context for biodiversity conservation was the development of new mechanisms of environmental governance introduced at the United Nations Conference on Environment and Development (UNCED), popularly known as the Earth Summit, held in Rio de Janeiro in 1992. The key institutional developments, relevant to NGCOs, emerging from this meeting were the CBD and the consolidation of the GEF. The development of these two institutions, however, and their implications for the work of conservation organizations was shaped by a much larger ideological struggle over the form that international environmental governance was to take. The contours of this struggle can be seen in events leading up to UNCED that positioned certain actors as central to the negotiations and others as more peripheral. Much of this struggle centered on the threat that emerging mechanisms of environmental governance posed to the private sector, particularly transnational corporations. Despite its status as an action plan based on the World Commission on Environment and Development (WCED), UNCED came to be viewed by business as a threat to the accrued benefits of neoliberalism and was, to some extent, seen as having the potential to encourage the enactment of strict regulatory control on the activities of the private sector, particularly the environmental degradation and 
social inequity associated with the operations of many transnational firms (Levy and Newell 2005; Rowe 2005).

In response to this perceived threat, business used its prior experience with UN activities in this area to prepare the ground for a central role in the UNCED process; particularly attempts by the UN Economic and Social Council established a Commission on Transnational Corporations (UNCTC) to monitor and provide reports on the activities of transnational corporations (TNCs) and to develop a comprehensive and legally binding UN Code of Conduct on TNCs that would enhance the capacity of developing countries to deal with serious social and environmental externalities that accompanied the tools of global capital. While these actions were curtailed by a coalition of governments, the Business and Industry Advisory Committee of the OECD and the International Chamber of Commerce (ICC), which worked through the OECD to develop an alternative, voluntary set of guidelines, this early attempt to impose environmental regulation on transnational corporations signaled the capacity of emerging international institutions to intervene and act in ways that threatened to make the accumulation of capital more complex. In response, business recognized that it needed to be much more proactive and better organized at the international level and began to organize in a coordinated way to shape the development of international environmental institutions (Bruno and Karliner 2002; Rowe 2005). This included the formation of the International Environmental Bureau within the ICC and the subsequent development of a Business Charter for Sustainable Development (Rose and Jackson 1992).

This proactive stance on the part of business meshed with a new view of global politics within the UN, manifest in the Brundtland Commission, which promoted dialogue among the world's governments and major non-governmental actors as the primary step in addressing global environmental problems: an approach that dominated planning for UNCED and screened the dialogue partners that would be involved in the UNCED process. This process based participation on the technocratic assumption that governments best expressed public interest while all other interests were, by definition, private and had an equal right to be heard by world leaders. In advance of the conference these private interests were asked to organize themselves into specific UNCED constituencies. ${ }^{15}$ However, these constituencies were clearly not viewed as equal and the International Finance Corporation and the UNCED Secretariat promoted some private sector organizations as privileged working partners of the UNCED process (Karliner 1999). Among these was the business sector in the form of the ICC that, with UNEP support, had successfully prepared itself by convening a World Industry Conferences on Environmental Management in 1984 and 1991 (Ford 2005). In 1990 Maurice Strong, the Secretary General 
of UNCED, and someone with a long history in the oil and energy business, appointed Swiss businessman Stephan Schmidheiny to be his chief advisor on business and industry and to lead business participation at the UNCED. Schmidheiny quickly convened the first Business Council for Sustainable Development, composed of CEOs of major global firms, to serve as an advisory group and structure the role of business in the negotiation of preparatory conventions leading up to UNCED. The Business Council for Sustainable Development developed a business perspective on environment and development challenges and designed a business vision of sustainable development that was thoroughly grounded in ecological modernization theory. ${ }^{16}$ As it became clear that it was no longer going to be possible to ignore environmental degradation or the environmentalism it had spawned, historical strategies of outright resistance to change gave way to strategies that sought to manage change. This move effectively sidelined the more critical stance of UNCTC, which had been working on relevant issues for over 15 years and had been slated to submit a series of recommendations to UNCED which would have imposed tough global standards on TNC activities. However, its submissions were never accepted or circulated to delegates. Rather, at the request of Strong, official "recommendations addressing transnational corporations... that governments might use in drafting Agenda 21" were provided by the Business Council for Sustainable Development (Bruno and Karliner 2002:36). Not surprisingly, these recommendations maneuvered to head off measures that would impose too heavy a cost on corporate activities and effectively blocked discussion of regulations as a mode of addressing the environmental impact of TNCs. Together with the ICC, and relevant national governments, the Business Council for Sustainable Development worked to ensure that Agenda 21 promoted voluntary self-regulation over other mechanisms to control the activities of TNCs (Karliner 1999; Rowe 2005). ${ }^{17}$ This outcome is what has led many critics to claim that UNCED was in fact planned to minimize change to the status quo and to evade the central social and environmental issues posed by continued consumption associated with conventional economic expansion (Finger 2005; Hildyard 1993; Sachs 1993). This is highlighted by the text of Agenda 21 that, echoing the Brundtland Commission, advanced a view of environmental and social problems as primarily the result of insufficient capital, inadequate technology, and a lack of management expertise. Accordingly, the anticipated solutions were new modes of capital generation, technology transfer from the North to the South; and the transfer of managerial logics and expertise.

This outcome is not particularly surprising given how the UNCED Secretariat effectively positioned the best-organized and financially powerful independent sectors as privileged working partners. Notably, these included not just business and industry but also 
establishment-oriented NGOs, in particular IUCN, WWF and the World Resources Institute, and UN agencies like UNEP. These alliances, however, were not at all new. UNEP and IUCN, for example, had longstanding relations prior to UNCED and had cooperated in the production of the World Conservation Strategy. UNEP also had links with business through a variety of programs meant to integrate concepts of sustainable development into business practice and had worked with the ICC to produce the World Industry Conferences on Environmental Management (Trisoglio and Kate 1991). These linkages are important primarily in relation to the framework conventions that were the primary product of UNCED. While the popular attention given to UNCED was seen as a threat by business, the real threat lay in the potential of its framework conventions, particularly the $\mathrm{CBD}$, to impose regulatory limits on access to "nature as capital".

\section{Institutional Enclosure and the Containment of the CBD}

In the years since UNCED, the business lobby has focused on ways to restrict the potential effects of the framework conventions on access to capital. This work was to some extent accomplished in the early drafting of the CBD which was, in its early versions, built on the platform of the World Conservation Strategy, a document already invested in an ecological modernization variant of sustainable development and used by the WCED to advocate for an international environmental convention that would designate species and genetic variability as common global heritage. This call was picked up by IUCN, which drafted legal articles that were subsequently submitted to a UNEP Ad Hoc Working Group of Experts on Biological Diversity and became the basis of draft articles for the CBD. Notably, whereas IUCN's articles dealt exclusively with biodiversity conservation and innovative mechanisms for its financing, the UNEP brief to negotiators set the tone of the final Convention text and sought to reconcile conservation with economic and technical progress by addressing:

...the economic dimension, including, inter alia, the question of adequate machinery for financial transfers from those who benefit from the exploitation of biological diversity, including through the use of genetic resources in biotechnology development, to the owners and managers of biological resources, and appropriate measures to facilitate the transfer of technical means of utilizing biological diversity for human benefit, will need to be properly considered in the negotiations of any future legal instrument for the conservation of biological diversity ... (UNEP 1989)

This brief deftly recognized the crux of the debate that would emerge around the convention. While the final text of the conventiondeveloped through a UN Intergovernmental Negotiating Committee 
that met five times prior to UNCED and represented most UN state members-listed the major objectives of the CBD as the conservation of biological diversity, the sustainable use of its components and the fair and equitable sharing of the benefits arising out of the use of genetic resources (Article 1), it was this last issue that has continued to be a thorn in the side of CBD negotiations. In the years since the CBD was opened, negotiations have continued to deal with the problem of "access and benefit sharing" and have failed to develop a legally binding international mechanism. The reasons for this revolve around the interests of states in protecting sovereign control over "natural resources", the interests of business in accessing genetic resources regardless of where they are located, and a realization on the part of poorer states that they could use the convention as an instrument to gain access to both technology and the bio-technology products developed through the alteration of their genetic resources (Arts 2006; Guruswamy 1999; Shime and Kohona 1992). Ironically, despite their role in the process, the CBD represents an outmaneuvering of conservation NGOs by national governments and the private sector. The loosely defined concept of sustainable development that NGCOs had used to motivate governments to deal seriously with the environmental consequences of state policy and practice was now being used to legitimize an agenda that prioritized economic growth over environmental protection and promised a new round of enclosure resulting from the imposition of new management regimes, capital flows and technology transfers.

The critiques of the CBD are well rehearsed (Brand and Görg 2008; McAfee 1999; Swanson 1999). Primary among these is that, first, it codifies a dominant perspective of nature as capital through its emphasis on sustainable use initiatives that, when translated into practice, means the use of in situ biodiversity to realize profit through the conversion of use value to exchange value; second, it positions biodiversity as genetic material available for exchange in a global market; and third, it explicitly recognizes that states have a sovereign right to determine access to genetic resources in their territories and to allocate the benefits from the use of those resources. ${ }^{18}$ These critiques carry over to the GEF which UNCED mandated as the financial mechanism to aid developing countries in achieving their commitments under the CBD. Donor countries, primarily the G7, fund the GEF largely as a matter of political will and replenish the fund in 4-year cycles. But these replenishments provide the opportunity for conditionality as donors articulate demands on ways in which GEF should modify structural processes, programming or funding priorities before they release new money. For example, during negotiations for the fourth replenishment of the GEF Trust Fund various donor governments led by the USA made future contributions contingent on the adoption of a performance-based resource allocation framework. 
They claimed that this would not only increase efficiency and equity on GEF project funding but "also guarantee project success by ensuring that GEF resources were channeled into properly developed "enabling environments" within recipient countries (Ervine 2007:132). Notably, "enabling environment" referred to the presence of a free market policy mix that reflected neoliberal economic practice including trade liberalization and privatization, and the presence of effective institutions to protect private property rights and promote an institutional environment conducive to business and investment. ${ }^{19}$

The CBD, like all international agreements, is more than simply a document; it is an institution that calls into being an active political space - an arena in which rights and interests may be negotiated and new social relations configured around those negotiations (see Strathern 2000). This arena can lead to creative opportunities for new, and previously excluded, groups to claim authority, but it also creates a context in which privileged positions and perspectives can be consolidated and codified in ways that structure policy and practice. The political space of the CBD, for example, has multiple locales. The most obvious are the biannual meetings of the Conference of the Parties (COP), convened by the Secretariat of the CBD, and the interim meetings of a variety of committees and ad hoc working groups that are open not only to CBD signatories but to a variety of civil society and private sector actors. The COP, however, is much more than simply a meeting of the parties. It is more apt to call it a stage - a space in which the range of interests that constitute a major element of environmental politics today perform and communicate their messages. This stage includes not only the continuing negotiations over the text of the convention and its programme of work, but the opportunity for a diversity of actors to make short statements advocating their positions in the presence of member states and to have these statements entered into record. More importantly, it provides a site where "stakeholders" can lobby member states and accommodates so-called "side events". These are sessions, much like those at the meetings of academic societies, which demonstrate projects or other experiences relating to implementation of the CBD and function as detailed lobby devices that seek to attract member state delegates and advocate positions in ways that might influence member state positions. ${ }^{20}$

Given the competition for attention at the COP meetings, programming of side events is important in influencing member state delegates, and to a remarkable degree, "the business delegation" has been able to acquire "prime-time" programming for its side events. More significantly, it has managed this with the direct assistance and resources of the CBD Secretariat (CBD Secretariat 2006a). For example, at the most recent COP-9 held in Bonn, Germany, while businessrelated side events ran throughout the meeting, they were concentrated 
during the high-level ministerial segment, a satellite meeting not open to regular attendees, in which government ministers meet together to consider some of the key political issues on the agenda of the COP. The ministerial segment is organized and hosted by the host government, which also chooses the issues for discussion. In Bonn, the German government chose to highlight its own business and biodiversity initiative at the expense of other issues of relevance to the convention. This was complemented by direct support from the CBD Secretariat which produced a calendar of business-related events at COP-9 "to help participants better plan their stay in Bonn" (CBD Secretariat 2008a). Despite the vast disparity of resources between the business delegation and other non-state actors legitimately involved in COP-9, and the organizational capacity of the business sector, business was the only delegation that received this level of support from the Secretariat. This explicit support for business is, on the surface, grounded in a decision approved at COP-8 in 2006 that encouraged "private-sector engagement" and took significant steps to incorporate business into Convention processes in ways that are not open to other participants. These included: urging national focal points of the CBD to work with national governments to encourage companies to engage in the development of national biodiversity strategies and action plans; persuading business representatives to participate in the meetings of the COP and other intergovernmental meetings; and, perhaps most significantly, encouraging:

national focal points, where appropriate, to include private sector representatives on national delegations to meetings of the Subsidiary Body on Scientific, Technical and Technological Advice, the Conference of the Parties, and other intergovernmental meetings, and nominate them to participate in technical expert groups ... (CBD Secretariat 2006b:260, original emphasis). ${ }^{21}$

The decision also committed resources to developing engagement with business by directing the Executive Secretary of the CBD Secretariat to "compile information on the business case for biodiversity and good biodiversity practice" and to "include the private sector as a target audience for its outreach materials". This directive to "engage" business, on behalf of parties, recognized that "contributions from business and industry" could be secured if work under the convention developed tools, and guidance "on biodiversity-related issues relevant to the private sector"; and "[t]ools for assessing the value of biodiversity and ecosystem services, for their integration into decision-making...".22 The Executive Secretary took this decision as a green light to engage with business in an explicitly proactive way and immediately following COP8 took the initiative to establish and staff a Business and Biodiversity initiative within the Secretariat, despite not having funding approval 
from the parties. Notably the head of this initiative, Nicholas Bertrand, came out of the Business and Biodiversity initiative that had earlier been established in IUCN.

This rhetoric of "engagement with business" and the degree to which the CBD is engaged in "courting" private sector actors overshadows the degree to which business has been engaged with the CBD since the UNCED and, in venues external to the realm of international environmental governance, has positioned itself as a central actor in attempts to operationalize an eco-modernist variant of sustainable development. It also obscures the foundational elements of the CBD that favour the privileged involvement of private sector actors. Primary among these was the push, from IUCN, in the initial drafts of the convention to develop new, "innovative" mechanisms for funding biodiversity conservation. This call was an implicit recognition of the constraining affect of neoliberalism on public spending for environmental protection and corresponded with IUCN's own initial ventures into market-based mechanisms to finance conservation (James, Green and Paine 1999; Lake 1997). It was also an explicit recognition that the programme of work developed by the convention and the obligations of state members, particularly those in so-called lessdeveloped regions, would require significant infusions of capital that would not likely be generated through contributions of direct foreign aid to biodiversity conservation. In implicit and not so implicit ways, COP documents have continually recognized the capacity of the private sector to fund the work of the convention. Indeed, corporate participation in the CBD has been legitimized by member states, and the Secretariat, through an eco-modernist rhetoric of environmental management that positions corporate actors as having the will, resources and knowledge to engage in environmental repair or caretaker services to solve the environmental problems that global capitalism has itself created.

The privileged position of business within the CBD process is a stark manifestation of the way in which capital operates at an international level to shape emerging institutions that would regulate access to and use of biodiversity (Newell 2005). It is clear, however, that this influence is not simply a function of direct lobbying on the part of business, but also stems from the structural power of corporations in state economies (Clapp 2005b; Levy and Egan 1998). Given the reliance of the capitalist state's resource strength on the revenue generated through the private accumulation of capital, the state is vested in serving the international interests of its most important corporate sectors. It is not surprising then that national positions seek not only to protect these interests in international conventions like the CBD but work to extend them. In passing COP decisions like VIII/3 referred to above, member states are officially signaling explicit approval for the privileged role of business in the CBD. In 
fact, this is consistent with policy developments in many member states that have adopted a neoliberal-inspired approach to environmental management and facilitated the direct involvement of business in policy formulation. As a result, some state delegates see the enhanced role of business in CBD negotiations as a legitimate and direct outcome of neoliberal policies and practices implemented at the national level. It is also consistent with a national-level withdrawal from regulatory oversight that encourages flexibility and the ongoing accumulation of capital from new markets built around "ecosystem services" and biodiversity investment opportunities (eg natural cosmetics, ecotourism, etc). Within a climate of expanding financial opportunity revolving around the development of these markets, states are not only eager to protect the rights of nationally based corporations to continue to access genetic resources internationally, but to structure that access in ways that enhance the revenue-generating potential of governments. The degree of state support for this form of engagement is apparent from the involvement of a diversity of state and para-state actors in socalled business and biodiversity initiatives. For example, in the 2 years between COP-8 and COP-9, a number of events were held that reveal the alignment between business, state and NGO actors. Particular among these are a number of international conferences like the Lisbon "High Level Conference on Business and Biodiversity", sponsored by the Portuguese presidency of the EU Council as part of an official priority area on business and biodiversity engagement that brought environment ministers and their staff together with CEOs of major agribusiness and extractive industry corporations, the staff of NGCOs, and the CBD and IUCN Secretariats. Indeed, the organizing committee for the meeting brought together senior representatives from the European Commission, the Portuguese government, the CBD Secretariat, the WBCSD, WWF International and IUCN, along with a number of business and biodiveristy consultants who rotate through these organizations. The themes of these conferences rarely deviate, and centre around the incorporation of biodiversity as an element of corporate social responsibility, tools for assessing business risks and opportunities associated with "ecosystem services", markets for biodiversity goods and services, and the facilitation of partnerships between industry and NGCOs. ${ }^{23}$ This type of event has become increasingly significant as a form of lobbying in relation to the emergence of international forms of environmental governance, for it rests upon a restricted and concentrated encounter between select representatives of business and government ministers, and is intentionally scheduled in order to allow for the lobbying of domestic governments before they send delegations off to international environmental negotiations (cf Clapp 2005a). This has long been a key strategy of business, but this kind of meeting marks a significant change in the way that governments are now allied with key 
business and NGO actors. It might in fact be better read as a visible expression of the way in which issues of biodiversity conservation and its governance configure particular elements of what Sklair (2000) has called a transnational capitalist class. ${ }^{24}$ In many ways, the lobbying is complete, blocs have been formed, and events like the Lisbon "High Level" conference ${ }^{25}$ reflect strategy and agenda setting moments in a hegemonic process that reflects the mutual capital interests of business, the state and $\mathrm{NGCOs}^{26}$.

My point in describing the positioning of business within the CBD process is to reveal how the convention structures a political dynamic in which capitalist interests seek to secure continued access to resources by using multiple channels of influence to shape policy. This is not necessarily a new observation. Studies of similar mechanisms of international environmental governance have pointed out that many large companies, industry groups, and researchers fear the development of an international regulatory structure beyond the national scale at which they have historically exercised interest (Levy 2005). Seeing the inevitability of some form of agreement, these actors set out to find ways to structure those agreements and seek compromises that limit regulatory control on the unfettered access to biodiversity that has characterized historic patterns of capital accumulation and protect their autonomy from the threat of more extensive international regulation (Levy and Newell 2002, 2005; Lipschutz and Rowe 2005). However, while the rhetoric that surrounds business engagement with the CBD creates the impression that outreach is required to convince business to become involved in CBD processes and in the issues dealt with by the convention, it is clear from a historical analysis that a transnational capitalist class composed of corporate executives, conservation professionals, politicians and bureaucrats have actively been developing mechanisms that would provide business with a privileged position in the convention process and through which mechanisms of international environmental governance like the CBD can be shaped in ways that accommodate the interests of capital accumulation and seek to control the conditions under which regulation is imposed. The WBCSD, for example, seeks a regulatory framework that would not limit access but would facilitate the development of markets and market mechanisms that offer "new business opportunities and the chance to use ecosystems and their services to tap into previously unrealized assets" (Stigson 2008:4). ${ }^{27}$

This positioning amounts to a form of what we might call institutional enclosure and can be read as a direct response to the threat initially posed by the CBD. In an age of global capitalism, unhindered transnational access to raw (including genetic) materials has been key to the accumulation of wealth. A rising concern with biodiversity protection as a key element of sustainability threatened to compromise access to those raw materials. When the threat of restriction was limited to 
protected areas, the threat to capital accumulation was not huge. But the CBD promised to go far beyond protected areas as a mechanism for protecting biodiversity, and created a significant degree of uncertainty about both the terms of access and the continued ability to deal directly with fairly malleable national governments outside of the frame of international guidelines or regulations. While the framing of the CBD incorporated an eco-modernist stance on sustainability from the outset, the convention created political space for a variety of actors to promote policy and regulatory interventions that were potentially damaging to the interests of capital. For example, much of the NGO and indigenous and local people's participation in CBD negotiations is grounded in ideological struggle to challenge singular definitions of biodiversity and to establish a regulatory framework for access and benefit sharing that accommodates diverse understandings of material and intellectual property, recognizes multiple forms of sovereignty, and fosters widely democratic involvement in formulation of equitable "access and benefit sharing" agreements. The potential of these groups to formulate and lobby for the implementation of an equitable access and benefit-sharing regime posed a direct threat to existing patterns of capital accumulation, particularly unhindered access to and use of resources. Business was alert to this "risk" from the outset and clearly saw a need to curtail this threat. The key to subordinating those threats posed by the convention was to enclose it ideologically and materially.

The degree of support for the interests of business among the primary institutional actors responsible for organizing the COP meetings of the $\mathrm{CBD}$, and particularly the explicit support of the Secretariat's Executive Secretary, suggests that business has achieved a position from which it can successfully minimize the threat that a concern with biodiversity protection poses to the continued access to resources and accumulation of capital. It has accomplished this in a number of ways including: the translation of its structural power in state economies into national support for an enhanced role in international institutions; and successfully focusing a transnational capitalist class on accumulation strategies as the solution to environmental degradation. This position also facilitates the use of the CBD and the GEF as instruments to extend practices of ideological and material domination that not only define nature as capital and assert the efficiency of market mechanisms as the most appropriate way to address environmental degradation and accordant losses of biodiversity, but that establish the conditions through which these mechanisms will be implemented. Notably, this process of institutional enclosure has precedent in the Parliamentary enclosures that accompanied the eighteenth-century annexation of the commons. A common characteristic of the spread of capitalist property relations has been the process of enclosure. Historically, enclosure amounted to a redefinition of property rights that included both the physical fencing 
in of lands to enable the exclusion of other potential users and the extinction of common and customary use rights. Wood (2002:108), among others, has noted that while the monarchical state in Europe initially resisted enclosure, "once the landed classes had succeeded in shaping the state to their own changing requirements ... there was no further interference, and a new kind of enclosure movement emerged in the eighteenth century, the so-called "Parliamentary enclosures". This phrase referred to the use of acts of Parliament-in a Parliament composed of landlords and lawyers - to abolish types of property rights that interfered with some landlords' powers of accumulation. We might think of institutional enclosure as akin to parliamentary enclosure- the use of the institutions of a governmental body in ways that served the interests of particular groups over others and was supported by the spread of an ideology of property which asserted the efficiency of privately enclosed land through the ability to realize economies of scale. If we view neoliberalism as a process in which a transnational capitalist class has shaped the state to its own requirements, structural control over new forms of international environmental governance that might challenge those requirements becomes a key component in reducing or eliminating obstacles to capital accumulation.

\section{Biodiversity and the Conservation of Organizations}

You know, if you're going to greenwash for these guys, you gotta ... if you're going to be a whore, you might as well be a high-priced whore (former Earthwatch senior executive, May 2008).

The position of structural control that business has strived to achieve in the $\mathrm{CBD}$ process is clearly related to broader trends in the reorganization of relationships between supra-state actors and the private sector. Symbolic of this trend is the UN's Global Compact initiative launched under Kofi Annan in 1999 that makes clear UN support for voluntary self-regulation and open markets, which "offer the only realistic hope of pulling billions of people in developing countries out of abject poverty, while sustaining prosperity in the industrialized world" (Annan 2000), and the role of $\mathrm{NGO} /$ private sector partnerships in both defining and pursuing this elusive goal. While this rhetoric sends a signal to UN agencies and associated organizations, it masks the shifting institutional context of these organizations and the asymmetrical power relations that have emerged since UNCED to facilitate ideological and material shifts within NGCOs. To understand the contemporary practice of biodiversity conservation, then, we need to understand this shifting institutional context, the power relations it brings into being, and the structural responses they generate from conservation organizations. 
The organizational environment of biodiversity conservation has become increasingly turbulent since UNCED. As mechanisms for international environmental governance have developed, new institutions and actors have become increasingly important components of the operating environment of conservation organizations. This turbulence creates substantial constraints for vulnerable organizations as the authority to set program agendas and funding become centralized and lead to the loss of a degree of autonomy in NGCOs. In the case of biodiversity conservation, the emergence of the CBD and GEF signaled a major shift in the institutional environment through their consolidation of state actors and the role of those actors in agreeing not simply on a centralized programme of work built around the convention but implicitly on ideological perspectives that guide the allocation of funds to carry out that work. In practice, then, the CBD programme of work, agreed upon by states, sets the biodiversity funding priorities and programme areas of the GEF, and diminishes the position of NGCOs in setting agendas upon which those programmes are based. In this altered institutional context, the project activities of NGCOs are structured by the environment in which the organization is embedded (Pfeffer and Salancik 2003). While it is important to recognize significant differences in the organizational histories, ideological bases and primary resource sources of conservation organizations, none of these organizations are self-contained or self-sufficient and all rely on an external environment to support their activities. ${ }^{28}$ It is this dependence on an external environment that not only makes the control of organizational behaviour possible but almost inevitable as NGOs need to be appropriately responsive to that environment to assure continued access to the resources they need to survive. Ironically, the growth of conservation organizations facilitated by neoliberalism in the 1970s and 1980s is partially responsible for their subordination as it developed an infrastructure grounded in short-term, project-based support rather than reliable core funding. This condition of scarce capital resources was actually intensified with the emergence of the GEF and its role of coordinating resource allocation in support of the work of the CBD, as it caused a shift of donor resources away from direct core funding support to conservation organizations and into projectbased funding in support of program areas aligned with the CBD. This provided the CBD Secretariat and the GEF significant power over the allocation of resources for biodiversity conservation. Just as importantly, the CBD programme of work acts as an explicit policy statement of member states, meaning that state moneys flowing to conservation organizations through other channels are more likely to come with conditionalities on their use that are tied to the CBD programme of work. 


\section{Organizational Adjustment to a New Insititutional Environment}

In confronting new institutional environments and their implicit demands, there are two broadly contingent adaptive responses: the organization can change to fit environmental requirements, or the organization can attempt to alter the environment so that it fits the organization's capabilities. These, however, are not exclusive responses and in many ways the changing operational context of conservation organizations represents a diversity of responsive actions to the new, and in some ways constraining, institutional context laid by the CBD. One clear response has been to seek out alternative sources of funding that maintains a measure of autonomy for the organization (Brechin 2008). Conservation International's long list of corporate donors (rather than partners) is likely the best example of this. Largely in the guise of purchasing corporate social responsibility, and achieving significant tax benefits, business donations provide a significant portion of Conservation International's operating budget. ${ }^{29}$ However, while Conservation International was developing alternative sources of capital, it was also engaged in the Critical Ecosystem Partnership Fund (CEPF), a GEF project, launched in 2000, that provides grants for NGOs and private sector partners to "help protect the Earth's biologically richest regions or hotspots" by creating "working alliances among diverse groups, combining unique capacities and eliminating duplication of efforts; and achieving "tangible results through an expanding network of partners working toward shared conservation goals" (GEF 2008:42). ${ }^{30}$ The CEPF is itself a partnership between the GEF, the World Bank, Conservation International the Government of Japan, and the MacArthur Foundation. This direct engagement of Conservation International with GEF, despite its success in developing alternative funding sources, is indicative of an attempt to match an institutional context with the organizations' capabilities, but also to use the institutional environment to advance the visibility and legibility of the organization. Given the easy recognition of the term "hotspots" as a legible Conservation International trademark, it is clear that the sole conservation organization in the CEPF venture is using the partnership fund as a vehicle to extend its influence and presence across the institutional environment. ${ }^{31}$

This move signifies that the organizational constraints around a new institutional environment involve not only a concern with continuing access, but also the legitimacy needed to continue to secure increasingly important project-based funding. It also indicates that a significant part of gaining this legitimacy includes the willingness and capacity to develop "working alliances". In an institutional environment, shaped by neoliberalism, that increasingly accommodates and privileges the interests of business in pursuing an eco-modernist version of sustainable 
development, access to the resources allocated through that institutional context relies on an organization visibly and legibly aligning its activities, capacities and objectives with the ideological and material interests of the dominant actors within that institutional context (Maragia 2002). Given these structural parameters, it is not surprising that many of the so-called integrated conservation and development programmes focused on the sustainable use of biodiversity, developed during the 1990s, were oriented toward addressing the funding initiatives of GEF/UNDP and not in an empirically informed understanding of grounded problems in their implementation sites (MacDonald 2005).

This perspective on the shift in an external environment and the subordinate position of conservation NGOs within that environment help to explain why "partnerships" between conservation organizations and corporate actors and the broader involvement of NGCOs in the promotion of business and biodiversity initiatives are growing so quickly, despite a long history of warranted distance. Despite the assertions of conservation organizations that the engagement is based on their mandate to influence society in the conservation of biodiversity, signals are clearly being sent from the institutional environment, largely through the structuring of programs and the availability of funding, that "engagement" with business is a priority. Managers within conservation organizations are exposed to these signals in a variety of ways and contribute to change in the organizational environment by simultaneously focusing work on these sectors and dedicating resources to develop the institutional capacity to carry out this work. This includes hiring staff with business backgrounds, developing specific units within the organization dedicated to both the development of partnerships with corporate actors and market-based conservation mechanisms that can act as the basis of project-based partnerships; and silencing the voices of those within the organization that might be resistant to these initiatives.

If the motivation for conservation organizations to engage with business resides in organizational responses to resource scarcity and the need to demonstrate ideological alignment with a new institutional context, the motivation for business to engage with conservation organizations lies more squarely in the need to control their own external environment in order to retain access and use rights to strategic resources, and to accommodate new institutional demands as cheaply as possible (Maxwell 1997). While the direct involvement of business in biodiversity conservation is often described as a form of greenwashing, this simplistic representation overlooks the extent to which conservation organizations have historically acquired a degree of authority and a capacity to influence governments in areas of environmental management, and been heavily critical of the role of industrial development in biodiversity loss and environmental degradation. With the global expansion of conservation during the 1980s, organizations 
also effectively positioned themselves as gatekeepers, particularly in low-income countries through their capacity to partner with governments, influence legislation, and help to generate project-based financing. This potential of conservation organizations to structure state policy and for certain units of conservation organizations to host oppositional voices have made it important to de-center conservation organizations as a site of effective action for critics, to dislocate them from the sphere of civil society, and to engage directly in reorienting their management practices and organizational structure (see McDonald in press).

From a business perspective, managers seek to maximize control and predictability over their operations. One way to achieve this is to incorporate all relevant actors that affect those operations within an interconnected system. As concerns with biodiversity protection have threatened the security of access to resources, or the use of genetic materials, it has become important to bring conservation organizations into that system. This provides business with a better understanding of its own external environment and with ways to intervene in that environment in an effort to protect its own interests. Bringing actors into this interconnected system is not necessarily easy, but it is a process in which business has substantial experience. This is evident in a description of the way in which an oil industry lobby group - the International Petroleum Industry Environmental Conservation Association (IPIECA) ${ }^{32}$-initially engaged IUCN:

[over a dinner speech] we had this little chat about looking for common ground and everything and they really loved it and so afterwards, ah, I did a few jokes and everything, and afterwards they um came up and said "well, we have this Special Issues Committee. We've got people working on this and that and oil spills and so on, but we've got this committee that looks at new and arising issues and we don't know what, we look at different things"... and biodiversity wasn't on the agenda. And I said "well you ought to look at biodiversity." And they said "well ... could we have our next meeting at your office? Could we just come down and meet you guys. So we'll have our meeting and we'll rent a room or whatever." I said, "nah, I'll give you a room. That's no problem." "And then maybe a few of your people could introduce themselves, and we could just sit and chat. We've never been to a place like IUCN." So I came back and said "well, the oil industry's going to come and have a meeting in our building." "WHAT???" HUH???" And so I said "yeah". So I got them to come and they all came. And this was Exxon, Mobil, Shell, BP. All their Heads of Health, Safety and Environment. Senior guys in the companies, you know. Alright, not the Chief Executives, but you know, you know, senior manager guys, global guys, from global headquarters. And one of the guys from one of the Australian oil companies comes and he, he kicks off ... And the 
guy from Australia puts up a little PowerPoint and he shows where all the Protected Areas are according to the WCMC up in Cambridge, and he's got the World Heritage sites and the parks and everything and then he overlays the PowerPoint where all the known oil reserves are for future exploration and it's [sound of a smack] you know ... and he says, "you know, where you guys are is where we want to be so we need to talk. We need to talk seriously" (former IUCN senior manager, May 2008).

This narrative is useful, in part, because it highlights how the engagement was initiated by business and not by the conservation organization, emphasizing that, despite the contemporary representations of outreach and exercising influence expressed by conservation organizations, business has historically sought to bring conservation organizations within their sphere of influence, and not necessarily vice versa. It also indicates that this engagement occurs when conservation exists as an obstacle blocking access to the resources that facilitate capital accumulation.

\section{"Engagement", Influence and Emerging Interdependencies}

"Engagement", however it is manifest, also helps to legitimate the presence and voice of business at international meetings like the CBD COP, where actors can profile their relationships as a way of gaining influence in the development of international regulatory mechanisms. Business, for example, readily displays representations of private sector/NGCO partnerships during COP meetings. And business delegates regularly refer to partnerships with conservation organizations in their official statements in the presence of delegates, as a way of demonstrating that they are, with jointly developed tools and the information that flows from partnerships, capable of addressing environmental problems that their sector may have caused in the past. The intent here is to use the partnership as a vehicle through which to promote voluntary agreements as an effective means of self-correction and to minimize the potential for restrictive regulation. However, partnerships not only enhance a corporation's public profile, but they can provide a cost savings to firms by effectively using public or donated moneys to fulfill legal or ethical obligations. While publicly released partnership agreements rarely disclose financial information on costs, terms of the partnerships typically position the conservation organization as a consultant, rather than a partner; providing a service to the industry group from which the industry group benefits but at a cost to the conservation organization or the broader public that provides core funding to that organization through government donations. ${ }^{33}$ For example, a recently signed agreement between IUCN and Holcim, a global supplier of cement, aggregates and concrete agreement, among 
other services, commits to the generation of "joint projects through a matching fund mechanism potentially leveraged with additional third party funds, recognizing that it will require patience and sustained effort over an extended period given the time-consuming approval processes of donors, especially in the public sector". ${ }^{34}$ Not only are public funds involved in meeting IUCN's obligations under this agreement, but IUCN commits the labour of its employees in an effort to raise public funds, that will, in essence, compensate a resource-rich private company to (perhaps) protect biodiversity and enhance its public reputation in the process. In many ways, this sort of framework agreement with the private sector is indicative of substantive ideological change within conservation organizations. It is grounded, at least superficially, in the same rhetoric of universal values that underpin the Global Compact, but is facilitated by ideological shifts within conservation organizations that have occurred over the past 20 years (Paine 2000). In substantial ways, the engagement with capital interests, which is justified by a rhetoric of influencing their behaviour in the interest of biodiversity conservation, has in fact facilitated substantial policy and program shifts within conservation organizations in ways that situate them as vehicles for the further accumulation of capital. It is not at all clear that these shifts achieve demonstrable gains for the conservation of biological diversity (Frynas 2005).

This ideological shift has occurred gradually in many organizations. Indeed, for most organizations, even those that tout their entrepreneurial origins, it does not appear to have happened in earnest until around 2000. In many ways conservation organizations are still feeling their way and seeking out guidelines on how best to engage with the private sector (Heap 2005). But the changes inside organizations that facilitate these shifts are apparent. Not only have specific units been developed in all major conservation organizations to manage private sector relations, but new, although unequal, interdependencies have arisen between the private sector and conservation organizations. In some cases these have taken the form of secondments of employees, but more significantly, private sector actors have been invited to adopt leadership positions within conservation organizations. In most cases this amounts to advisory panels, such as IUCN's "Leaders for Nature", or WWF's Corporate Club, but in other cases it extends to more substantive positions such as Conservation International's Chairman's Council and TNC's Board of Directors. ${ }^{35}$ This can occasionally lead to public relations problems when the increasingly close alignment between NGCO and private sector interests becomes too public and the potential for a conflict of interest too great. Perhaps the highest profile case of late has been the potential threat to IUCN's credibility when Valli Moosa, President of IUCN and former Minister of Constitutional Development and Minister of Environment in South Africa's government accepted 
the position as Chairperson of Eskom, South Africa's notorious state energy company while retaining his position as President of IUCN. The fact that Moosa continued to hold these positions simultaneously is a mark of how deep the interconnection between the private sector and conservation organizations like IUCN has become.

It is also a mark of the degree to which a near universal conflation of nature and capital has established itself as a dominant view within NGCOs. Other similar signs include the organizational effort with which they have engaged in the development of new forms of coordinated production and investment that promote programs to create markets for ecosystem services, venture capital programs designed to facilitate the growth of small biodiversity businesses, and offset programs to compensate for concentrated biodiversity impacts, among other initiatives. These shifts stem from an acceptance of eco-modernist equations of sustainable development with continued expansion in economic productivity, a recognition of the threat that environmental degradation poses to conventional modes of production, and a belief that imagining into being new markets and opportunities for accumulation are the basis for addressing these problems. As it says on the WWF International website, "The panda means business". ${ }^{36}$ But the panda didn't always mean business. At a point in the not too distant past, the easily recognizable WWF symbol meant the development of effective public engagement in the protection of wildlife habitat. The shift in the meaning of the symbol, indeed its conversion from symbol to legally protected brand, indicates a shift in the recognition of what and who are currently in a position to best contribute the support necessary for the organization to continue its activities. ${ }^{37}$ Increasingly, these are the individuals who anchor the business and biodiversity and private sector partnership programs that help to secure resources and confer legitimacy on the organization in relation to dominant ideological perspectives and associated resource opportunities in the institutional environment of biodiversity conservation.

\section{Conclusion: New Contexts, New Friends and New Goals}

The development of an institutional context, accordant with the demands of neoliberal capitalism, over the past 20 years has situated biodiversity conservation organizations in radically new ways. The speed with which conservation organizations have adopted both the accordant rhetoric and practice of "private sector engagement" points to the way in which "organizations are not so much concrete social entities as a process of organizing support sufficient to continue existence" (Pfeffer and Salancik 2003:24). Organizations, as coalitions, are dynamic. They alter their purposes and their spheres of authority to accommodate the interests of new dominant actors and shed parts of their structures that 
are overtly resistant to this change. It is this organizational characteristic of modernist conservation that subordinates it, at different points in time and space, to larger societal political projects such as imperialism, nationalism, and over the last two decades, neoliberal capitalism. The tendency to think of organizations as engaged in static, coherent, activities like "biodiversity conservation", for example, is mistaken. Once we recognize that an ideological and material project like biodiversity conservation is inseparable from larger political projects that define the constitution, and subsequent use of "biodiversity" and modes of "conservation", we can take seriously the observation that capitalist development is integrally an environmental project that operates through the restructuring of socionatural relations (Prudham 2004). But what is key here is that this restructuring is an organized practice, by which I mean simply that it occurs through organizations that are increasingly shaped by the eco-modernist imperatives of capitalist development. This makes it markedly important that we consider the role played by organizational concerns in restructuring nature-society relations.

I have described how the neoliberal restructuring of biodiversity conservation is an iterative process that is not separate from the interests of the organizations that increasingly claim responsibility for the global management and protection of biodiversity. Indeed, many of these organizations are responsible for mobilizing the conditions that led to their own subordination within an institutional environment that was not simply amendable to the interests of capital accumulation but was shaped from the outset by those interests. Much of this is related to the growth of conservation organizations, specifically during the 1980s, a growth that was itself facilitated by the neoliberal practices of multilateral financial institutions. That growth became a way to justify organized conservation and its activities, which came to be viewed as worthwhile and important, partially as a result of that growth. But it also placed conservation organizations in a vulnerable position in terms of maintaining that commitment, and increasingly tied them to an external environment dominated by neoliberal policies and practices. Removing this uncertainty was in part the motivation for pushing the development of an international convention to deal with problems of biodiversity loss and to coordinate work to reduce the impact of economic growth on biodiversity. In many ways, conservation organizations saw this as a route to extend their influence and to develop the organization as a site of greater authority, power and prestige. However, they were outmaneuvered by business as the loose rhetoric of sustainable development that they developed to legitimate that new institutional context opened up a new field of ideological struggle and created space for a particularly conservative variant of environmentalism-ecological modernization-to achieve a dominant position and to subsequently 
reconfigure discourses and practices of environmental management and protection according to a logic of capitalist market relations. That these discourses and practices have subsequently so successfully taken root in biodiversity conservation organizations is not simply a function of organizational dependence on dominant actors for resources, but reflects the outcome of a political class struggle that has successfully incorporated senior actors in conservation organizations within the interconnected system of a transnational capitalist class. ${ }^{38}$ This is profoundly important because, for this class, ecological modernization has a rational and material core that does address real problems- the problems that historical modes of biodiversity conservation posed to the continued accumulation of capital. And it is through the dominant position of this class that neoliberalism and ecological modernization have not only acquired a purchase on conservation practice around the world, but have become written into the materiality of biodiversity. The organization of biodiversity conservation has been successfully restructured so that it serves capitalist expansion, just as it once served imperialist and nationalist expansion.

\section{Endnotes}

1 IUCN, which celebrated its 60th anniversary in 2008, is a "union" composed of membership organizations; a secretariat of permanent staff and six volunteer-based Commissions. The membership has historically been composed of non-governmental organizations and State members. Private sector membership has been prohibited by statute, although there have been attempts from within the Secretariat and beyond to allow private sector organizations to join. Initially, IUCN was composed of volunteer experts who compiled data on conditions affecting species dynamics, but through the 1980s it expanded its number of permanent staff, established regional programme offices around the world and became directly involved in project implementation (see MacDonald 2003 on the structure of IUCN). This has caused conflict with member organizations who have come to see the Secretariat as a direct competitor for the project funds that help to maintain smaller conservation organizations.

2 http://www.foei.org/en/publications/pdfs/iucn-withdrawal (last accessed 27 February 2009). In October 2007, IUCN signed an agreement with Royal Dutch Shell with the goal of influencing Shell's biodiversity conservation performance. Similar partnerships were signed with Holcim, the leading global supplier of cement, and Total, the French oil giant. In the pipeline is an agreement with Rio Tinto, the world's largest coal extractor. ${ }_{3}$ http://news.bbc.co.uk/2/hi/science/nature/7654721.stm (last accessed 27 February 2009).

4 Notably, 15 governments did vote for termination of the agreement.

5 The IUCN Director General (head of the Secretariat and tasked with carrying out the will of the membership), for example, could be seen enthusiastically pumping her fist and mouthing the word "Yes!" when the motion was defeated.

${ }^{6}$ In absolute numbers, state members comprise a significant minority of IUCN membership. However, some states provide substantial framework funding to the organization and others are effective institutional partners in many parts of the world, facilitating the project work of IUCN offices. The IUCN Secretariat would have difficulty continuing to function without the support of state members, and states would have little incentive to belong to IUCN if they did not have the ability to shape organizational policy. 
Given this mutual reliance it is unlikely that the bicameral structure of IUCN is likely to change any time soon. At the same time, there is growing discontent among NGO members over the capacity of states to block the popular will of the membership.

7 The observations in this paper are grounded in fieldwork that has involved participation involving assessment of IUCN field projects, work within an IUCN Commission over the last decade, and participation in both World Conservation Congresses and CBD Conference of the Parties meetings.

8 By modernist conservation, I mean the policies, programs and projects of large international conservation agencies, and national governments. This is not to assign any priority to this work but to distinguish it from the many small-scale conservationist practices that fall outside of this domain.

9 Understanding the relation between conservation policy and practice and larger social and political projects is one important reason for undertaking research that tracks structural change within conservation organizations.

10 The normalization of the term "business" in academic literature as a uniform constituency is problematic as it glosses over substantial diversity among actors that would fall within the category. When I use the term in this paper it is in part because that is the term that has come to prominence with the biodiversity conservation community. But it is meant to signify something more; specifically lobby groups that function as "collective individuals" or those "entrusted with the activities of organizing the general system of relationships external to business itself" (Gramsci 1971:6). The International Chamber of Commerce (ICC 2008), for example, in its briefings to the Convention on Biological Diversity asserts positions on behalf of "the business delegation". Similarly, the ICC and the World Business Council on Sustainable Development (WBCSD) created the Business Action for Sustainable Development (BASD) prior to the World Summit on Sustainable Development in 2002 to, in their own words, "ensure business rallies its collective forces for the UN World Summit on Sustainable Development"; Bruno and Karliner 2003:17). The first head of the BASD was Sir Mark Moody-Stuart, a former Shell CEO.

11 Critical analysis of many of these programs has effectively pointed out the flawed assumptions upon which they were based, including an assumed universal economic rationalism, and poorly informed constructions of the "community" concept. Notably few of these programs conducted detailed ethnographic research in their project areas to test the assumptions upon which programming was based (Brosius and Tsing 1998; Li 2007; MacDonald 2005).

${ }^{12}$ I use the word "rightly" here in its moral sense for the proponents of ecological modernization are making the moral claim that the market ought to be the primary mode of engaging in environmental protection.

13 I use articulation in both senses of the word here. Not only are an increasing number of the publications and web pages of conservation organizations related to ecological modernization programming, but the offices of conservation organizations are sites where interactions between relevant actors occur (for example, IUCN and Shell employees are exchanged through a secondment program). See, for example, IUCN's Business and Biodiversity Programme; Conservation International's Center for Environmental Leadership in Business; WWF's International's Corporate Club; the Secretariat for the Convention on Biological Diversity's Business and Biodiversity Initiative.

14 Not the least of the problems with these programs is their reductionist understanding of the constitution of community (Brosius and Tsing 1998).

15 These constituencies included non-governmental organizations, inter-governmental organizations, Indigenous and local peoples, business, and education, among others.

16 The Business Council for Sustainable Development was renamed the World Business Council on Sustainable Development and now claims over 200 CEOs as members. It 
was heavily involved in the "Business and Biodiversity Journey" during the 2008 World Conservation Congress and is engaged in a mutual secondment program with the IUCN Secretariat.

17 According to Peter Hansen, former director of UNCTC, in the preparatory meetings for UNCED, "The U.S. and Japan ... made it quite clear that they were not going to tolerate any rules or norms on the behaviour of the TNCs, and that any attempts to win such rules would have real political costs in other areas of the negotiations" (Bruno and Karliner 2002:26).

18 While article $8 \mathrm{j}$ of the CBD sets out that the knowledge and practices of indigenous and local peoples are to be respected and protected, these are still subordinated to the sovereignty of the nation state.

19 These reforms generated significant resistance from the G77 and China who saw them as the basis for excluding countries based on macro-political assessments (country scores on GEF Benefits and Performance Indexes) carried out by the World Bank. The Benefits Index claims to measure a country's potential to "generate global environmental benefits" while the Performance Index measures "capacity to successfully implement GEF programs and projects based on its current and past performance" (GEF 2005).

20 After a side event, it is common to hear organizers ask "how many delegates attended and where were they from?"

21 Notably several delegations, including the Netherlands and Australia, have regularly included representatives from business, "thus facilitating, inter alia, regular communication with the business observers to these meetings" (CBD Secretariat 2008b:11).

22 These recommendations, however, did not come out of the blue but were based on ongoing initiatives by Brazil's Ministry of the Environment, the UK Department for Environment, Food and Rural Affairs, IUCN, the Brazilian Business Council for Sustainable Development, Insight Investment and the Executive Secretary of the CBD, to "develop ideas, that could best be pursued through the Convention or in support of its objectives, for engaging business in biodiversity issues" (CBD Secretariat 2006b:2).

23 Notably a framework agreement signed by IUCN and Holcim, Europe's largest cement and aggregates firm was being hailed in meeting documents as a "successful partnership", despite the fact that the agreement was signed in February 2007, just 9 months before the Lisbon meeting, before any active project work had begun, and before any independent review of the partnership.

${ }^{24}$ While the social relations that underpin this configuration are often hidden from view, as in the "high level ministerial" segments of the CBDCoP, or the annual economic summit at Davos - which has, for a number of years, attracted the heads of key environmental organizations-other meetings have become important as field sites that render the existence of a transnational class visible, sometimes in spectacular ways. For example, the opening plenary sessions of the 2008 World Conservation Congress were steeped in references to oligarchical relations of power that bridged a feudal past and a corporate future. The presence of European royalty, representatives of the state, and business was announced to the assembled audience who were made to wait while a procession of VIPs, distinguished by red neck straps entered the hall. Keynote speakers like Ted Turner and Mohammed Yunus served as proxy celebrities but had nothing to say about biodiversity or its conservation. However, that was not their function-they were there in an attempt to draw attention to IUCN and, by virtue of their celebrity, to confer authority on the WCC, much as Royalty represented a sort of consecration. Perhaps most importantly, they were there to facilitate the personal and organizational objectives of the senior IUCN leadership to secure access to the potentially beneficial resources of a more extensive organizational network. Even at the WCC, however, key private sector, state and organizational actors gathered in much more intimate, exclusive, and class-structured environs away from the Congress venue that included the 
yacht of a Saudi prince anchored in Barcelona harbor, among other sites spread around the city.

25 Presumably a term designed to increase the attendance of those who prefer to think of themselves as "high-level" actors.

${ }^{26}$ For example, the closing roundtable of this meeting included the Director General of IUCN, the Executive Secretary of the CBD Secretariat, a former President of the European Investment bank, the president of Portugal's largest private employer, the Minister's of Environment of present and future EU Presidencies, and the Minister of Environment for Germany, who would hold the presidency of the CBD COP in Bonn in 2008. The topic was "the next steps for business and biodiversity in Europe".

27 This statement by the President of the WBCSD reveals a particular Lockean view of "natural capital", suggesting that "making the business case for biodiversity" is about exposing its capacity to make a profit. Locke's nature was "waste" for one reason only-its failure to realize a profit. Accordingly, "the business case for biodiversity" is not about conserving the ecological functioning of biodiversity but of reclaiming the "waste" from its unpriced services, imagining into being new forms of economic productivity, and more specifically the conversion and application of this productivity to commercial profit. It is this application of intellectual, rather than physical, labour to nature that constitutes contemporary "improvement".

28 As an example, Conservation International and IUCN have markedly different resource bases. Conservation International relies much more heavily on direct corporate donations to finance their work while IUCN is heavily reliant on project funds from donor governments and multi-lateral financial institutions.

$2956.5 \%$ of Conservation International's 2006 budget was drawn from corporations and foundations. Notably there is often an overlap between these two. Conservation International, for example, has received significant donations from the Walton Family Foundation, much of which is derived from profits provided by investments in WalMart. They also have a direct "partnership" arrangement with Wal-Mart focused on energy and waste reduction and the development of products geared toward an "environmentally conscious" consumer; in essence doing the work of cost reduction and product development for one of the world's largest corporations. TNC and WWF have also effectively tapped into corporate and private donations as a way of addressing capital constraints; $\mathrm{cf}$ Brechin 2008).

30 See Litzinger (2006) for a critical appraisal of these "shared conservation goals".

31 Notably the former Chief Conservation and Science Officer at Conservation International has become Team Leader, Natural Resources Division at GEF.

32 IPIECA is the CSR arm of the oil and gas industry and was established in 1974 following the establishment of UNEP. IPIECA provides one of the industry's principal channels of communication with the UN (http://www.ipieca.org/).

33 The IUCN Secretariat response to the motion to terminate the agreement with Shell, for example, warned of a direct capital loss to the Secretariat and unknown liability costs: "Core funding on the order of CHF 1,300,000 would not be available if the agreement is terminated. Further negative financial consequences may be incurred depending on the conditions of the termination of the agreement" (IUCN 2008).

$34 \mathrm{http} / / / \mathrm{cms}$.iucn.org/about/work/programmes/business/bbp_our_work/bbp_holcim/ (accessed 24 June 2008).

35 Some within the IUCN Secretariat have also openly promoted the alteration of the organization's constitution to allow private sectors members. IUCN, as a union of actors concerned with nature conservation, has historically restricted membership to state and non-governmental actors.

36 http://www.panda.org/about_wwf/how_we_work/businesses/index.cfm

37 Branding is not inconsequential in the sphere of conservation organizations. As organizations, under the guidance of communications consultants, become increasingly 
concerned with "message control", they also become increasingly focused on the value of their brand and associate trademarks. A case in point is the drawn-out legal struggle between the World Wide Fund for Nature and the former World Wrestling Federation over the right to use the acronym WWF (Davies 2002).

38 As an indication, consult the list of VIPs present during the 2008 World Conservation Congress http://cmsdata.iucn.org/downloads/vip_list_for_congress.pdf

\section{References}

Adams W and Hutton J (2007) People, parks and poverty: Political ecology and biodiversity conservation. Conservation and Society 5:147-183

Annan K (2000) Secretary-General welcomes international corporate leaders to global compact meeting. Press release No UNIS/SG/2618, 27 July http://www.unis. unvienna.org/unis/pressrels/2000/sg2618.html (last accessed 21 July 2008)

Arts B (2006) Non-state actors in global environmental governance: New policy arrangements beyond the state. In M Koenig-Archibugi and M Zürn (eds) New Modes of Governance in the Global System: Exploring Publicness, Delegation and Inclusiveness ( $\mathrm{pp}$ 177-201). London: Palgrave Macmillan

Ashford N A (2002) Government and environmental innovation in Europe and North America. American Behavioral Scientist 45:1417-1434

Beder S (2006) The changing face of conservation: Commodification, privatization and the free market. University of Wollongong, Faculty of Arts Papers No 40

Bernstin, S (2001) The Compromise of Liberal Environmentalism. New York: Columbia University Press

Brand U and Görg C (2008) Sustainability and neoimperial-liberal globalization: A theoretical perspective. In J Park, K Conca, M Finger and (eds) Sustainability, Globalization, and Governance (pp 13-33). London: Routledge

Brechin S (2008) Private sector financing of international biodiversity conservation: An exploration of the funding of large conservation NGOs. Paper presented at the Capitalism and Conservation Symposium, University of Manchester, 8-10 September

Brosius P and Tsing A (1998) Representing communities: Histories and politics of community-based natural resource management. Society and Natural Resources 11:157-169

Bruno K and Karliner J (2002) Earthsummit.biz: The Corporate Takeover of Sustainable Development. Oakland: Food First Books

CBD Secretariat (2004) Business and Biodiversity Initiatives: A Background Document for the Business and the 2010 Biodiversity Challenge Meetings in London, 20-21 January 2005. Montreal: Convention on Biological Diversity

CBD Secretariat (2006a) Believing in business and biodiversity. Business 2010 1:1, 12

CBD Secretariat (2006b) Report of the Eighth Meeting of the Parties to the Convention on Biological Diversity Decision VIII/17, Private-Sector Engagement, UNEP/CBD/ COP/8/31, 15 June, http://www.cbd.int/doc/meetings/cop/cop-08/official/cop-08-31en.pdf (last accessed 21 July 2008)

CBD Secretariat (2008a) Business at COP-9: A guide, http://www.cbd.int/cop9/ business/biz-cop9-guide-en.pdf (last accessed 21 July 2008)

CBD Secretariat (2008b) Cooperation with other conventions, international organizations and initiatives and engagement of stakeholders: Addendum engagement of business. Note by the Executive Secretary, UNEP/CBD/COP/9/21/Add.1, 27 March, http://www.cbd.int/doc/meetings/cop/cop-09/official/cop-09-21-add1-en.pdf (last accessed 21 July 2008)

Clapp J (2005a) Global environmental governance for corporate responsibility and accountability. Global Environmental Politics 5:23-34 
Clapp J (2005b) Transnational corporations and global environmental governance. In P Dauvergne (ed) Handbook of Global Environmental Politics (pp 284-297) Northampton, MA: Edward Elgar

Conservation International (2005) Center for Environmental Leadership in Business: 2005 Annual Report. Washington DC: Conservation International

Coronil F (2000) Towards a critique of globalcentrism: Speculations on capitalism's nature. Public Culture 12:351-374

Davies I (2002) Legal update: The panda vs. the rock. Journal of Brand Management 9:210-214

Ervine K (2007) The greying of green governance: Power politics and the Global Environment Facility. Capitalism, Nature, Socialism 18:125-142

Finger M (2005) The new water paradigm: The privatization of governance and the instrumentalization of the state. In D L Levy and P Newell (eds) The Business of Global Environmental Governance (pp 275-304). Boston: MIT Press

Flitner M (1999) Biodiversity: Of local commons and global commodities. In M Goldman (ed) Privatizing Nature: Political Struggles for the Global Commons (pp 144-166). New Brunswick: Rutgers University Press

Ford L H (2005) Challenging the global environmental governance of toxics: Social movement agency and global civil society. In D L Levy and P Newell (eds) The Business of Global Environmental Governance (pp 305-328). Boston: MIT Press

Frynas J G (2005) The false developmental promise of Corporate Social Responsibility: Evidence from multinational oil companies. International Affairs 81:581-598

GEF (2005) Resource Allocation Framework. Global Environmental Facility: Washington DC

GEF (2008) Financing the Stewardship of Global Diversity. Global Environmental Facility: Washington DC

Geisinger A (1999) Sustainable development and the domination of nature: Spreading the seed of the western ideology of nature. Boston College Environmental Affairs Law Review 27:43-73

Gramsci A (1971) Selections from the Prison Notebooks of Antonio Gramsci. New York: International Publishers

Gulbrandsen T C and Holland D C (2001) Encounters with the super-citizen: neoliberalism, environmental activism, and the American Heritage Rivers Initiative. Anthropological Quarterly 74:124-134

Guruswamy LD (1999) The convention on biological diversity: Exposing the flawed foundations. Environmental Conservation 26:79-82

Hajer M (1995) The Politics of Environmental Discourse: Ecological Modernization and the Policy Process. Oxford: Clarendon

Hayden C (2003) When Nature Goes Public: The Making and Unmaking of Bioprospecting in Mexico. Princeton: Princeton University Press

Heap J (2005) A Survey of Guidelines for Not-For-Profit/Private Sector Interaction. Gland: IUCN

Hildyard N (1993) Foxes in charge of the chickens. In W Sachs (ed) Global Ecology: A New Arena of Political Conflict (pp 22-35). London: Zed Books

ICC (2008) Access and Benefits Sharing: General Observations and Positions Submitted for the 9th Conference of the Parties of the UN Convention on Biological Diversity. International Chamber of Commerce, http://www.iccwbo.org/uploadedFiles/ICC/ policy/intellectual_property/Statements/ABS\%20submission\%20COP-9\%20final\% 2016-05-08.pdf (last accessed 18 July 2008)

IUCN (2006) Business and Biodiversity Programme 2005 Annual Report. Gland: The World Conservation Union 
IUCN (2008) Corrigendum, Motions: World Conservation Congress, Barcelona, Spain, 5-14 October 2008. Gland: The World Conservation Union, http://cmsdata.iucn.org/ downloads/rwg_comment_for_31mot.pdf (last accessed 15 September 2009)

James A N, Green M J B and Paine J R (1999) A Global Review of Protected Area Budgets and Staff (WCMC Biodiversity Series No 10). Cambridge: World Conservation Press

Jamison A (1996) The shaping of the global environmental agenda: The role of non-governmental organizations. In S Lash, B Szerszynski and B Wynne (eds) Risk, Environment and Modernity: Towards a New Ecology (pp 224-245). London: Sage

Karliner J (1999) A Perilous Partnership: The United Nations Development Programme's Flirtation with Corporate Collaboration. San Francisco: Transnational Resource and Action Centre, http://www.corpwatch.org/article.php?id=3388 (last accessed 21 July 2008)

Keil R and Desfor G (2003) Ecological modernization in Los Angeles and Toronto. Local Environment: The International Journal of Justice and Sustainability 8:27-44

Lake R (1997) New and Additional?: Financial Resources for Biodiversity Conservation in Developing Countries 1987-1994. Cambridge: Royal Society for the Protection of Birds

Lapham N P and Livermore R J (2003) Striking a Balance: Ensuring Conservation's Place on the International Biodiversity Assistance Agenda. Washington DC: Center for Applied Biodiversity Science, Center for Conservation and Government, Conservation International

Levy D L (2005) Business and the evolution of the climate regime: The dynamics of corporate strategies. In D L Levy and P Newell (eds) The Business of Global Environmental Governance (pp 73-104). Boston: MIT Press

Levy D L and Egan D (1998) Capital contests: National and transnational channels of corporate influence on the climate change negotiations. Politics and Society 26:337-361

Levy D L and Newell P J (2002) Business strategy and international environmental governance: Toward a neo-Gramscian synthesis. Global Environmental Politics 2:84101

Levy D L and Newell P (2005) The Business of Global Environmental Governance. Boston: MIT Press

Li T (2007) Will to Improve: Governmentality, Development, and the Practice of Politics. Durham: Duke University Press

Lipschutz R D and Rowe J K (2005) Globalization, Governmentality and Global Politics: Regulation for the Rest of Us? London: Routledge

Litzinger R A (2006) Contested sovereignties and the Critical Ecosystem Partnership Fund. Political and Legal Anthropology Review 29:66-87

MacDonald K I (2003) IUCN-The World Conservation Union: A history of constraint. Paper presented to the Permanent Workshop of the Centre for Philosophy of Law Higher Institute for Philosophy of the Catholic University of Louvain (UCL), Belgium, 6 February, https://tspace.library.utoronto.ca/handle/1807/9921 (last accessed 5 February 2009)

MacDonald K I (2004a) Developing "nature": Global ecology and the politics of conservation in northern Pakistan. In J G Carrier (ed) Confronting Environments: Local Environmental Understanding in a Globalizing World (pp 71-96). Walnut Creek: Alta Mira Press

MacDonald K I (2004b) Conservation as cultural and political practice. Policy Matters 13:6-17

MacDonald K I (2005) Global hunting grounds: Power, scale and ecology in the negotiation of conservation. Cultural Geographies 12:259-291 
MacDonald K T (in press) Business, biodiversity and new "fields" of conservation: The World Conservation Congress and the renegotiation of organizational order. Conservation and Society

Mansourian S and Dudley N (2008) Public Funds to Protected Areas. Gland: WWF International

Maragia B (2002) Almost there: Another way of conceptualizing and explaining NGOs' quest for legitimacy in global politics. Non-State Actors and International Law 2:301332

Maxwell J (1997) Green schemes: Corporate environmental strategies and their implementation. California Management Review 39:118-133

McAfee K (1999) Selling nature to save it? Biodiversity and the rise of green developmentalism. Environment and Planning D: Society and Space 17:133-154

Mol A P J and Spaargaren G (2000) Ecological modernization theory in debate: A review. Environmental Politics 9:17-49

Newell P (2005) Business and international environmental governance. In D L Levy and P Newell (eds) The Business of Global Environmental Governance (pp 21-47). Boston: MIT Press

O'Connor M (1994) Is Capitalism Sustainable? Political Economy and the Politics of Ecology. New York: Guilford Press

Paine E (2000) The Road to the Global Compact: Corporate Power and the Battle Over Global Public Policy at the United Nations. New York: Global Policy Forum, http://www.globalpolicy.org/reform/papers/2000/road.htm\#31 (last accessed 18 July 2008)

Pearce D and Palmer C (2001) Public and private spending for environmental protection. Fiscal Studies 22:403-456

Pfeffer J and Salancik G R (2003) The External Control of Organizations: A Resource Dependence Perspective. Stanford: Stanford University Press

Prudham S (2004) Poisoning the well: Neoliberalism and the contamination of municipal water in Walkerton, Ontario. Geoforum 35:343-360

Redclift M (1995) The environment and structural adjustment. Journal of Environmental Management 44:55-68

Reed D (1992) Structural Adjustment and the Environment. Boulder, CO: Westview Press

Reimann K D (2006) A view from the top: International politics, norms and the worldwide growth of NGOs. International Studies Quarterly 50:45-67

Rose G and Jackson S (1992) Industry's response to UNCED: Environmental management post-Rio. Review of European Community and International Environmental Law 1:320-324

Rowe J K (2005). Corporate social responsibility as business strategy. In R Lipschutz and J K Rowe (eds) Globalization, Governmentality and Global Politics: Regulation for the Rest of Us? (pp 30-46). London: Routledge

Sachs W (1993) Global ecology in the shadow of development. In W Sachs (ed) Global Ecology: A New Arena of Political Conflict (pp 3-21). London: Zed Books

Shine C and Kohona P T B (1992) The Convention on Biological Diversity: Bridging the gap between conservation and development. Review of European Community and International Environmental Law 1:278-288

Sklair L (2000) The transnational capitalist class and the discourse of globalization. Cambridge Review of International Affairs 14:67-85

Sneddon C S (2000) "Sustainability" in ecological economics, ecology and livelihoods: A review. Progress in Human Geography 24:521-549

Stigson B (2008) Business and biodiversity. IUCN Pan-European Newsletter 15:3-5

Strathern M (2000) Multiple perspectives on intellectual property. In K Whimp and M Busse (eds), Protection of Intellectual, Biological and Cultural Property in Papua 
New Guinea (pp 47-61). Canberra: Asia Pacific Press at the Australian National University

Swanson T (1999) Why is there a biodiversity convention? The international interest in centralized development planning. International Affairs 75:307-331

Taylor P J and Buttel F H (1992) How do we know we have global environmental problems? Science and the globalization of environmental discourse. Geoforum 23:404-416

Tokes D (2001) Ecological modernisation: A reformist review. New Political Economy 6: $279-291$

Trisoglio A and ten Kate K (1991) From WICEM to WICEM II: A Report to Assess the Progress in Implementation of WICEM Recommendations. Geneva: UNEP

Turner T (1982) Scuttling environmental progress. Business and Society Review 42:4852

UNEP (1989) Preparation of an International Legal Instrument on the Biological Diversity of the Planet. UNEP 15th Governing Council Session, 25 May, http://www. unep.org/Documents.Multilingual/Default.Print.asp?DocumentID=71\&ArticleID= 963\&l=en (last accessed 3 August 2008)

WCED (1987) Our Common Future. Oxford: Oxford University Press

Wood E (2002) The Origin of Capitalism: A Longer View. London: Verso

Worster D (1993) The shaky ground of sustainability. In W Sachs (ed) Global Ecology: A New Arena of Political Conflict (pp 134-144). London: Zed Books 